\title{
High Performance Concrete
}

\author{
Shanagonda Akhila ${ }^{1}$, Kolla Aswani Chandh ${ }^{2}$ \\ 1,2 Department of Civil Engineering, Vignan's Institute of Technology and Aeronautical Engineering, \\ Vignan hills Deshmukhi(V) Nalgonda (Dist)
}

\begin{abstract}
High performance concrete (HPC) has been defined as concrete that possesses high workability, high strength and high durability. American concrete institute (ACI) has defined HPC as a concrete in which certain characteristics are developed for a particular application and environment. Under the ACI definition durability is optional and this as led to a number of HPC structures, which should theoretically have had very long services lives, exhibiting durability associated distress early in their lives. ACI also define a high-strength concrete as concrete that has a specified compressive strength for design of 6000 psi (41 MPa) or greater. High performance concrete (HPC) is a concrete made with appropriate materials combined according to a selected mix design; properly mixed, transported, placed, consolidated and cured so that the resulting concrete will give excellent performance in the structure in which it is placed, in the environment to which it is exposed and with the loads to which it will be subjected for its design life. Mix proportions for high performance concrete (HPC) are influenced by many factors, including specified performance properties, locally available materials, local experience, personal preferences, and cost. With today's technology, there are many products available for using concrete to enhance its properties. The primary application for HPC have been structures requiring long service lives such as oil drilling platform, long span bridges and parking structures. HPC still requires good construction practice and good curing to deliver high performance.
\end{abstract}

Keywords: Fly Ash, Super plasticizer, Compressive strength, Flexural strength, Split Tensile strength, HPC

\section{Introduction}

The American Concrete Institute (ACI) defines highperformance concrete as concrete meeting special combinations of performance and uniformity requirements that cannot always be achieved routinely when using conventional constituents and normal mixing, placing and curing practices. A high-performance concrete is something which demands much higher performance from concrete as compared to performance expected from routine concrete.

High Performance Concrete (HPC) is designed to provide several benefits in the construction of concrete structures as tabulated below:

\section{Performance Benefits}

- Ease of placement and consolidation without affecting strength

- long-term mechanical properties

- early high strength

- toughness

- volume stability

- longer life in severe environments

\section{Cost \& Other Benefits}

- Less material

- Fewer beams

- Reduced maintenance

- Extended life cycle

- Aesthetics

A high-strength concrete is always a high-performance concrete, but a high-performance concrete is not always a high-strength concrete.

\section{Materials Used}

1) Cement
2) Fine Aggregate
3) Coarse Aggregate
4) Fly Ash
5) Super Plasticizer

\section{Tests Conducted}

\subsection{Cement}

Zuari 43 grade ordinary Portland cement is used for casting the elements. The following test are conducted

1) Fineness test

2) Standard consistency test

3) Initial setting time test

4) Final setting time test

5) Specific gravity test

6) Compressive strength test

\subsection{Fine Aggregate}

In this investigation fine aggregate is a naturaly available sand and it is free from dirt, dust and any organic matter. The fine aggregate used for the project was obtained from Krishna river.

The following tests were conducted on the sand:

1) Sieve analysis

2) Bulking of sand by volume method.

3) iii.Specific gravity test.

\subsection{Coarse Aggregates}

In this investigation hard broken granite aggregate is used. The size aggregate is various from $12 \mathrm{~mm}$ to $20 \mathrm{~mm}$. The source the aggregates is Kavadpalli.

The following tests were conducted on the Coarse Aggregates 


\section{International Journal of Science and Research (IJSR) \\ ISSN (Online): 2319-7064}

Index Copernicus Value (2015): 78.96 | Impact Factor (2015): 6.391

1) Specific Gravity

2) Fineness Modulus

3) Water Absorption

4) Aggregate Impact Test

5) Aggregate Crushing Test

\subsection{Fly Ash}

Finely divided residue that results from the combustion of ground or powdered coal." It is primarily the inorganic portion of the source coal in a particulate form. Fly ash is a very fine material consisting predominantly of small spheres of glass. The material once considered as a waste by product, finding difficulty to be disposed off, has now become a material of considerable value, when used in connection with concrete as an admixture.

The following fly ash tests are discussed in detail:

1) Moisture content,

2) Loss on ignition,

3) Silicon oxide content,

4) Alumina oxide content,

5) Calcium oxide content,

6) Chloride content,

7) Free calcium oxide content,

8) Total alkali oxides content,

9) Particle density determination (by Pycnometer bottle and Le-Chatlier Flask methods),

10) Fineness determination (by dry sieving, wet sieving, Blaine air permeability and laser methods)

The following tests for fly ash cement pastes, mortars, or concretes are outlined:

1) Soundness (expansion test),

2)water requirement (expressed as water content of test specimen divided by water content of control specimen to achieve equal specified consistencies)

3)Preparation and curing of specimens, determination of compressive strength (28 days).

\subsection{Super Plasticizers}

Plasticizers or water reducers, and super plasticizer or high range water reducers, are chemical admixtures that can be added to concrete mixtures to improve workability.

In order to produce stronger concrete, less water is added (without "starving" the mix), which makes the concrete mixture less workable and difficult to mix, necessitating the use of plasticizers, water reducers, super plasticizers or dispersants. Plasticizers are also often used when pozzolanic ash is added to concrete to improve strength. This method of mix proportioning is especially popular when producing high-strength concrete and fiber-reinforced concrete.

Adding 1-2\% plasticizer per unit weight of cement is usually sufficient. Adding an excessive amount of plasticizer will result in excessive segregation of concrete and is not advisable. Depending on the particular chemical used, use of too much plasticizer may result in a retarding effect.
Table 1: Property of Super Plasticizers

\begin{tabular}{|c|c|}
\hline Usage & High-range water reducing type super plasticizer \\
\hline Classification & Polycarbixylate based super plasticizer \\
\hline Appearance & Light brown liquid \\
\hline Solid Content & Min. $40 \%$ \\
\hline $\begin{array}{c}\text { Viscosity } \\
\left(25^{\circ} \mathrm{C}\right)\end{array}$ & Max. $1000 \mathrm{cPS}$ \\
\hline Density & $1.10-1.20 \mathrm{mg} / 1$ \\
\hline $\mathrm{Ph}$ & $4.0-7.5$ \\
\hline
\end{tabular}

\subsection{Tests Conducted on HPC}

\subsubsection{Compressive Strength Test \\ 3.6.2 Split Tensile Strength \\ 3.6.3 Flexural Strength Test}

\section{Results}

Table 2: Test Results on Cement

\begin{tabular}{|c|c|c|c|c|}
\hline S.No & Test Name & \multicolumn{3}{|c|}{ Result } \\
\hline 1 & sieve test & \multicolumn{3}{|c|}{$8 \%$} \\
\hline 2 & standard consistency & \multicolumn{3}{|c|}{$29 \%$} \\
\hline 3 & Initial setting time & \multicolumn{3}{|c|}{$52 \mathrm{~min}$} \\
\hline 4 & Final setting time & \multicolumn{3}{|c|}{$480 \mathrm{~min}$} \\
\hline 5 & Specific gravity test & \multicolumn{3}{|c|}{3.15} \\
\hline \multirow[t]{2}{*}{6} & \multirow[t]{2}{*}{ Compressive strength } & $\begin{array}{l}3 \text { days } \\
\mathrm{N} / \mathrm{mm}^{2}\end{array}$ & $\begin{array}{c}7 \text { days } \\
\mathrm{N} / \mathrm{mm}^{2}\end{array}$ & $\begin{array}{l}28 \text { days } \\
\mathrm{N} / \mathrm{mm}^{2}\end{array}$ \\
\hline & & 22.12 & 30.12 & 44.23 \\
\hline
\end{tabular}

Table 3: Test Result on Fine Aggregate

\begin{tabular}{|r|c|c|}
\hline S. No & Test Name & Result \\
\hline 1 & Sieve analysis & Zone 111 \\
\hline 2 & Bulking of sand by volume method & $12.5 \%$ \\
\hline 3 & Specific gravity test & 2.51 \\
\hline 4 & Relative density & $45 \%$ (medium dense) \\
\hline
\end{tabular}

Table 4: Test Result on Coarse Aggregate

\begin{tabular}{|c|c|c|}
\hline S.No & Test Name & Result \\
\hline 1 & Fineness modulus & 7.5 \\
\hline 2 & Specific gravity & 2.83 \\
\hline 3 & Water absorption & $2.1 \%$ \\
\hline 4 & Crushing strength & $22.43 \%$ \\
\hline 5 & Impact test & $28.12 \%$ \\
\hline
\end{tabular}

Table 5: Test Result on Compressive Strength

\begin{tabular}{|c|c|c|c|}
\hline Specifications & \multicolumn{3}{|c|}{ Compressive strength $\left(\mathrm{N} / \mathrm{mm}^{2}\right)$} \\
\hline Addition of fly ash & 3 days & 7 days & 28 days \\
\hline $0 \%$ & 26.68 & 29.77 & 45.77 \\
\hline $10 \%$ & 25.44 & 32.22 & 50.44 \\
\hline $20 \%$ & 24.58 & 34.60 & 52.33 \\
\hline $30 \%$ & 23.58 & 35.56 & 55.56 \\
\hline $40 \%$ & 22.98 & 28.25 & 44.23 \\
\hline Super plasticizers & & & \\
\hline $0 \%$ & 26.68 & 29.77 & 45.77 \\
\hline $0.50 \%$ & 29.11 & 32.85 & 54.12 \\
\hline $1 \%$ & 30.01 & 35.98 & 54.85 \\
\hline $1.50 \%$ & 30.98 & 36.01 & 55.12 \\
\hline $2 \%$ & 25.12 & 28.12 & 44.85 \\
\hline
\end{tabular}




\section{International Journal of Science and Research (IJSR) \\ ISSN (Online): 2319-7064}

Index Copernicus Value (2015): 78.96 | Impact Factor (2015): 6.391

Test Result Explained by the Following Graphs.

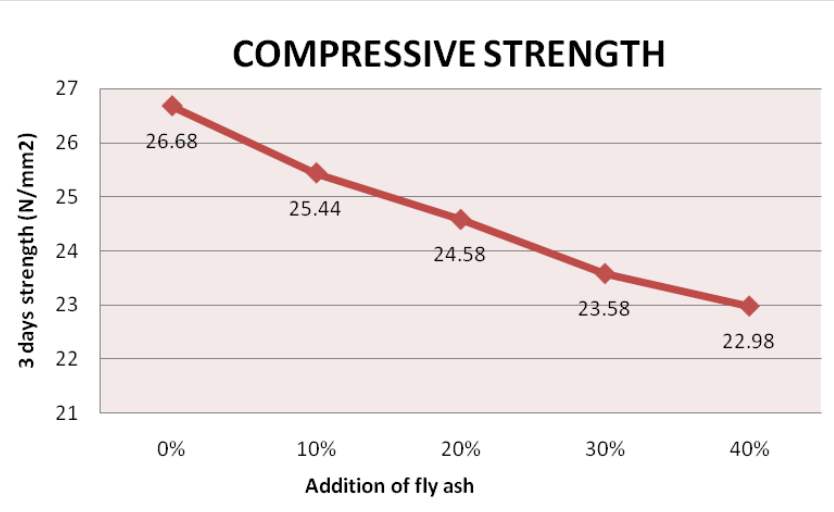

Figure 1: Graph Drawn between Compressive Strength Vs Addition of Fly Ash for 3 days

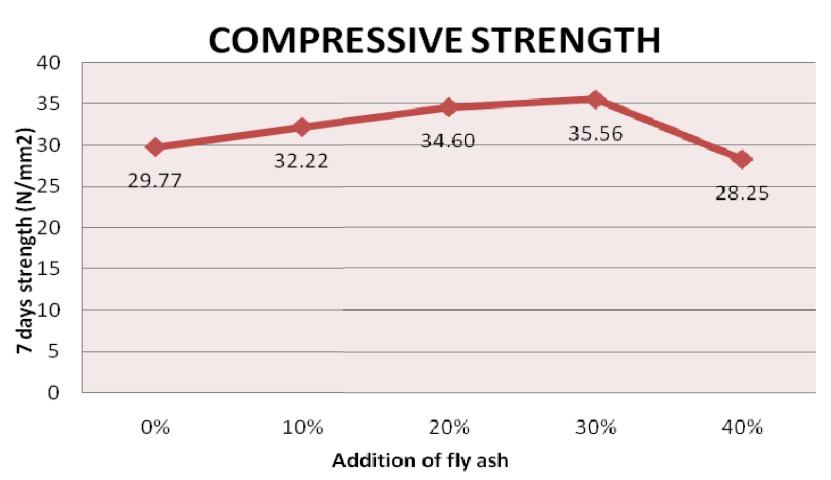

Figure 2: Graph Drawn between Compressive Strength Vs Addition of Fly Ash for 7 days

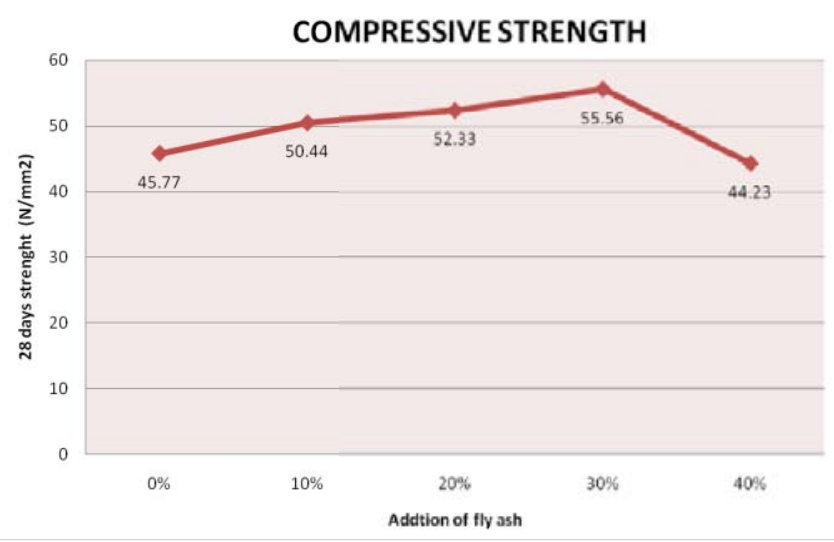

Figure 3: Graph Drawn between Compressive Strength Vs Addition of Fly Ash for 28 days

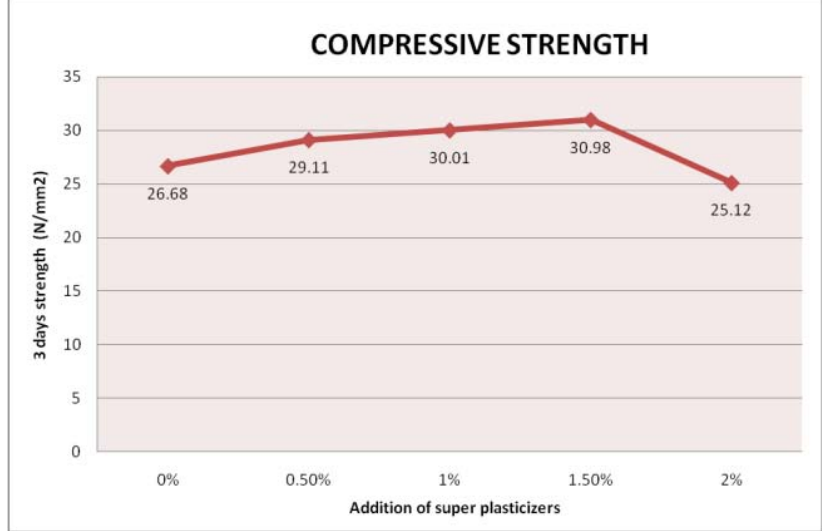

Figure 4: Graph Drawn between Compressive Strength Vs Addition of Super Plasticizer for 3 days

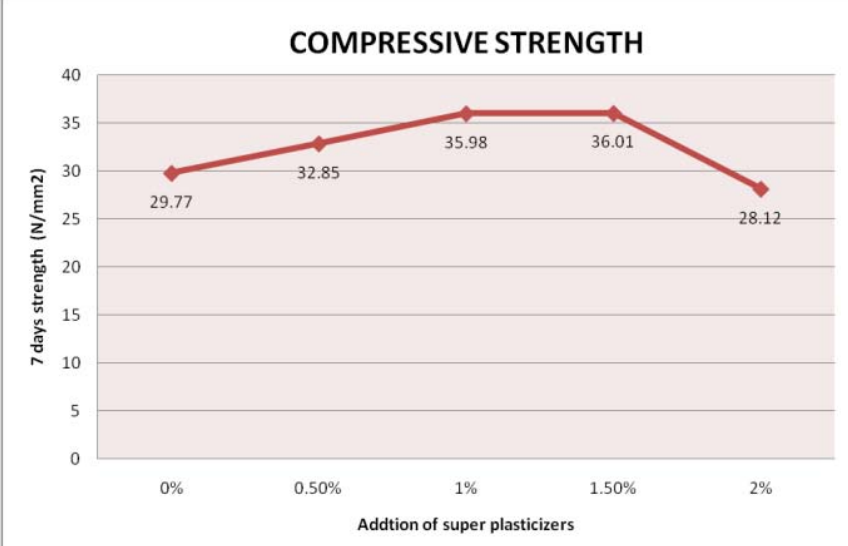

Figure 5: Graph Drawn between Compressive Strength Vs Addition of Super Plasticizer for 7 days

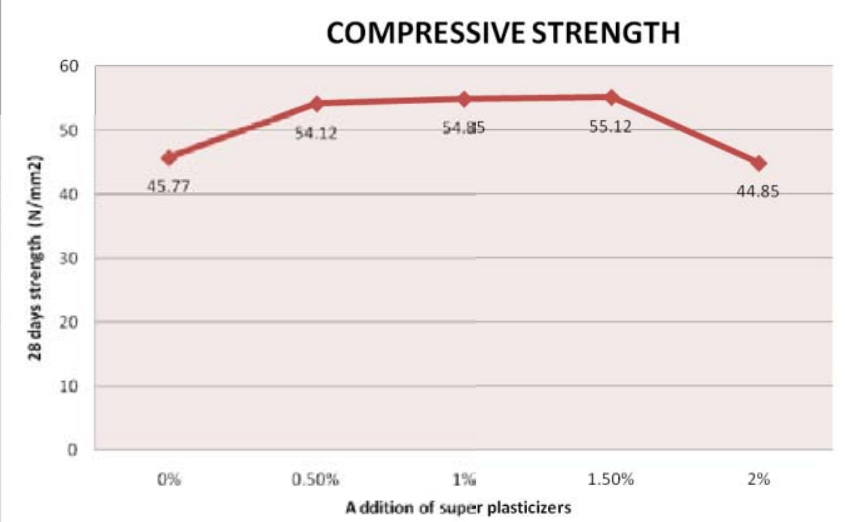

Figure 6: Graph Drawn between Compressive Strength Vs Addition of Super Plasticizer for 28 days

Table 6: Test Result on Split Tensile Strength

\begin{tabular}{|c|c|c|c|}
\hline Specifications & \multicolumn{3}{|c|}{ Split tensile strength $\left(\mathrm{N} / \mathrm{mm}^{2}\right)$} \\
\hline Addition of fly ash & 3 days & 7 days & 28 days \\
\hline $0 \%$ & 2.26 & 2.50 & 3.00 \\
\hline $10 \%$ & 2.40 & 2.68 & 3.51 \\
\hline $20 \%$ & 2.60 & 2.90 & 3.53 \\
\hline $30 \%$ & 2.70 & 3.08 & 3.70 \\
\hline $40 \%$ & 2.16 & 2.55 & 2.8 \\
\hline Super plasticizers & & & \\
\hline $0 \%$ & 2.26 & 2.67 & 2.9 \\
\hline $0.50 \%$ & 2.70 & 3.20 & 3.54 \\
\hline $1.0 \%$ & 2.87 & 3.35 & 3.68 \\
\hline $1.50 \%$ & 2.96 & 3.45 & 3.72 \\
\hline $2.0 \%$ & 2.22 & 2.54 & 2.85 \\
\hline \multicolumn{4}{|l}{} \\
\hline
\end{tabular}

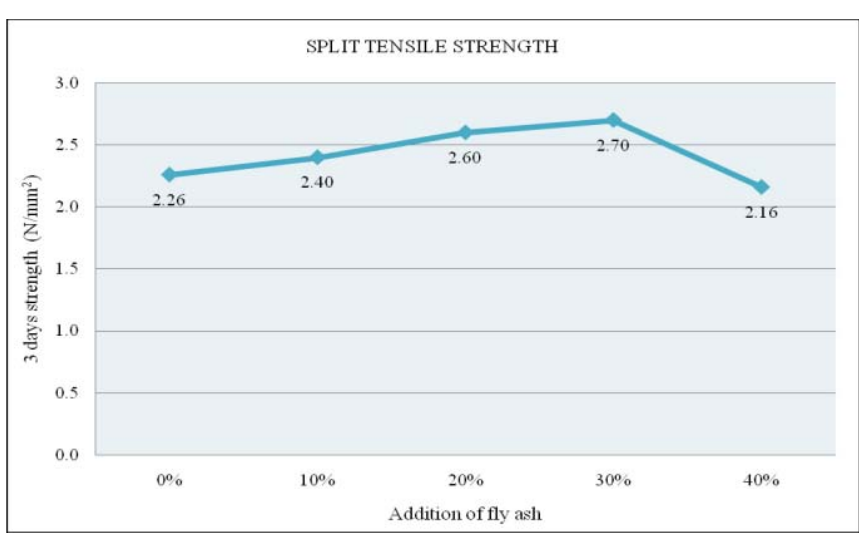

Figure 7: Graphs Drawn between Split Tensile Strength Vs Addition of Fly Ash for 3 days

\section{Volume 6 Issue 1, January 2017 www.ijsr.net}




\section{International Journal of Science and Research (IJSR) \\ ISSN (Online): 2319-7064}

Index Copernicus Value (2015): 78.96 | Impact Factor (2015): 6.391

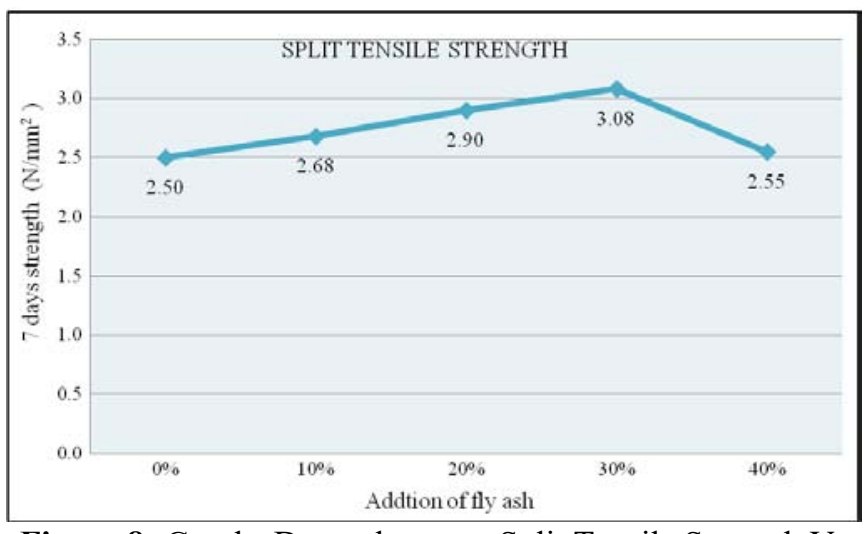

Figure 8: Graphs Drawn between Split Tensile Strength Vs Addition of Fly Ash for 7 days

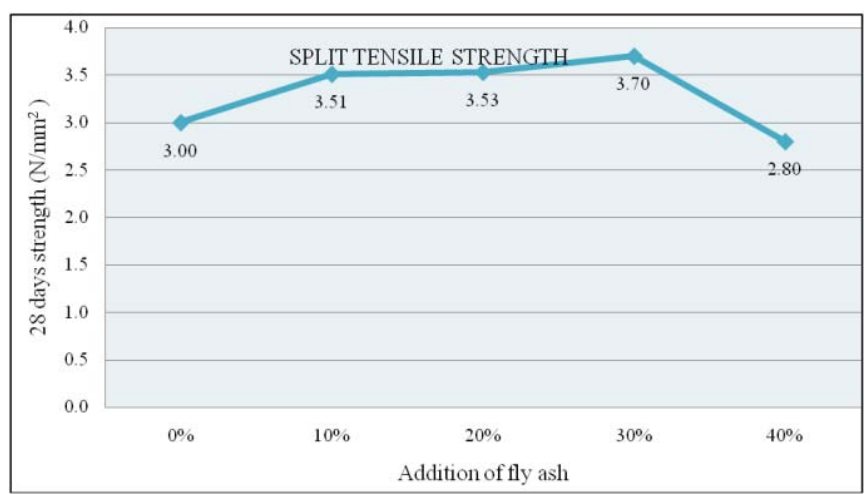

Figure 9: Graphs Drawn between Split Tensile Strength Vs Addition of Fly Ash for 28 days

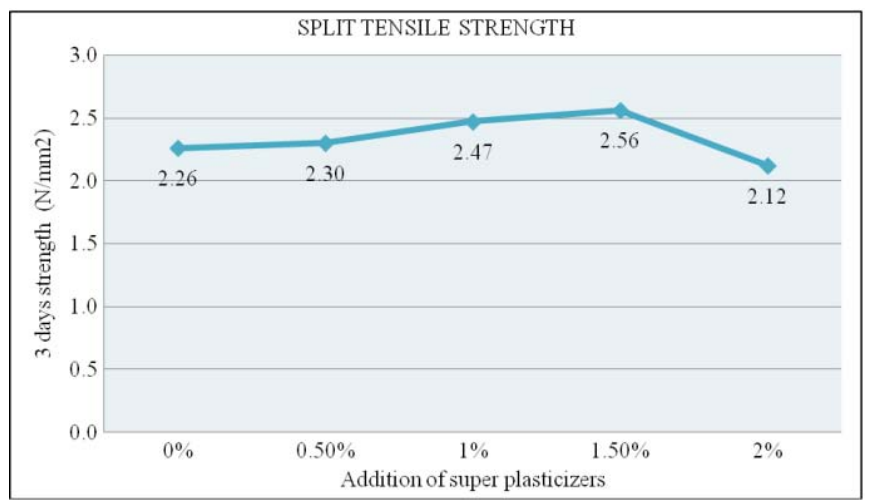

Figure 10: Graphs Drawn between Split Tensile Strength Vs Addition of Super Plasticizer for 3 days

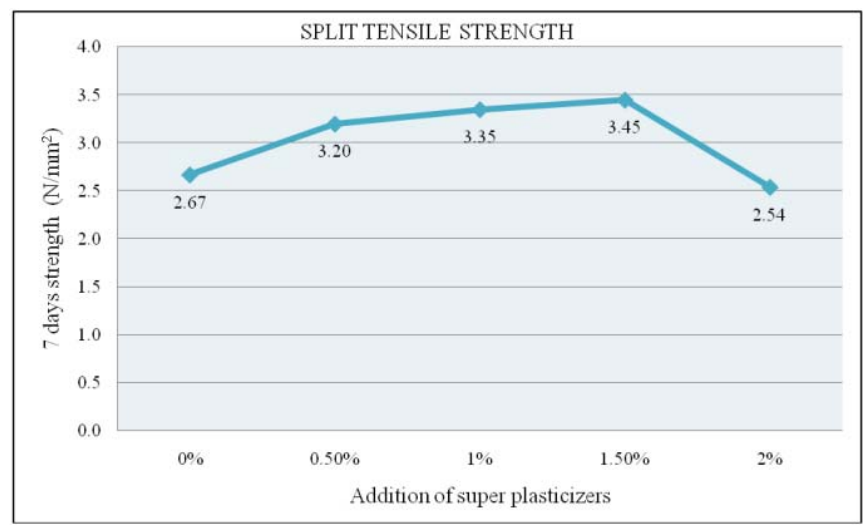

Figure 11: Graphs Drawn between Split Tensile Strength Vs Addition of Super Plasticizer for 7 days

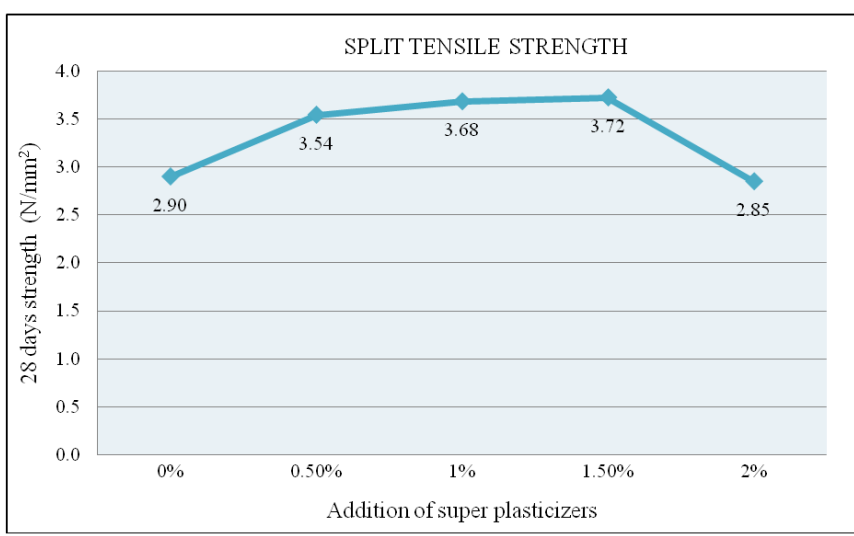

Figure 12: Graphs Drawn between Split Tensile Strength Vs Addition of Super Plasticizer for 28 days

Table 7: Test Results on Flexural Strength

\begin{tabular}{|c|c|c|c|}
\hline Specifications & \multicolumn{4}{|c|}{ Flexure strength $\left(\mathrm{N} / \mathrm{mm}^{2}\right)$} \\
\hline Addition of fly ash & 3 days & 7 days & 28 days \\
\hline $0 \%$ & 3.12 & 5.45 & 7.05 \\
\hline $10 \%$ & 4.25 & 5.7 & 7.42 \\
\hline $20 \%$ & 5.12 & 6 & 7.92 \\
\hline $30 \%$ & 5.25 & 6.2 & 8.05 \\
\hline $40 \%$ & 3.02 & 5.35 & 6.95 \\
\hline Super plasticizers & & & \\
\hline $0 \%$ & 3.12 & 5.45 & 7.05 \\
\hline $0.50 \%$ & 4.62 & 5.90 & 7.12 \\
\hline $1 \%$ & 4.82 & 5.98 & 7.35 \\
\hline $1.50 \%$ & 4.91 & 6.01 & 7.48 \\
\hline $2 \%$ & 3.00 & 5.32 & 6.95 \\
\hline
\end{tabular}

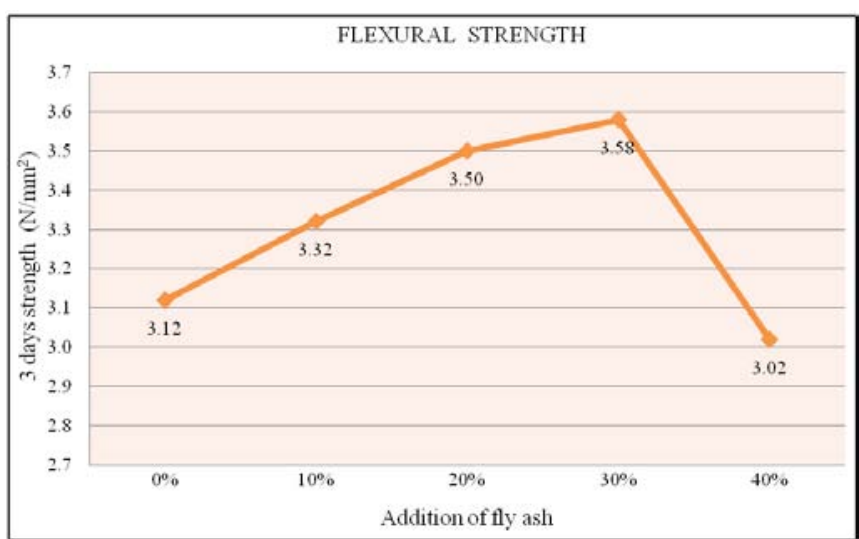

Figure 13: Graphs drawn between Flexural strength vs Addition of fly ash for 3 days

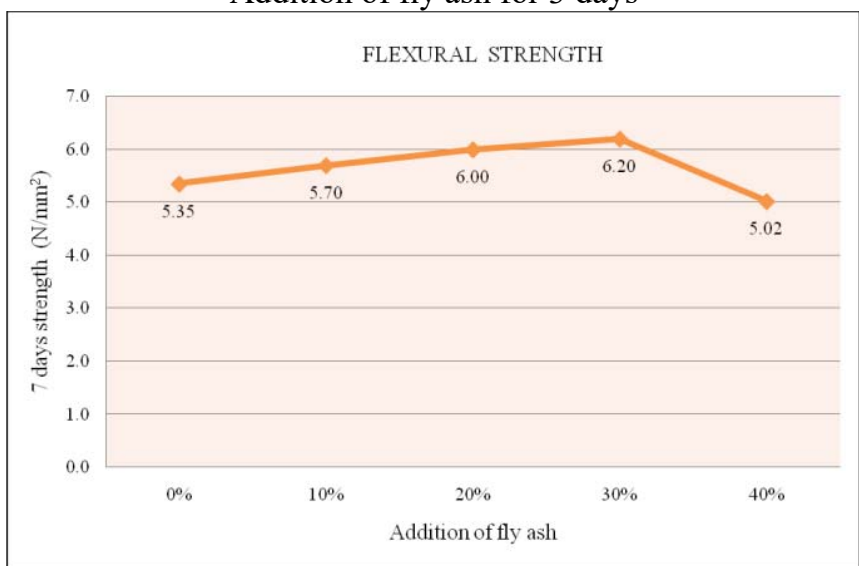

Figure 14: Graphs drawn between Flexural strength vs Addition of fly ash for 7 days

Volume 6 Issue 1, January 2017

www.ijsr.net

Licensed Under Creative Commons Attribution CC BY 


\section{International Journal of Science and Research (IJSR)}

ISSN (Online): 2319-7064

Index Copernicus Value (2015): 78.96 | Impact Factor (2015): 6.391

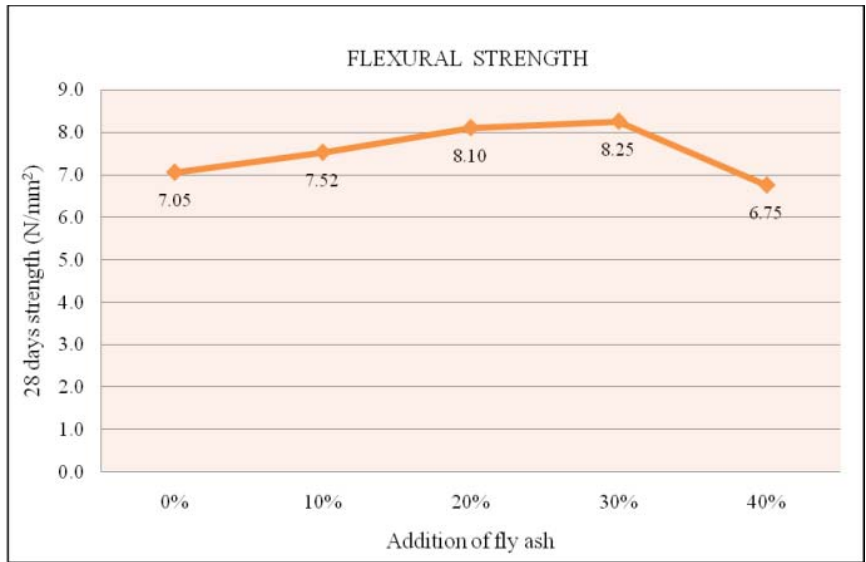

Figure 15: Graphs drawn between Flexural strength vs Addition of fly ash for 28 days

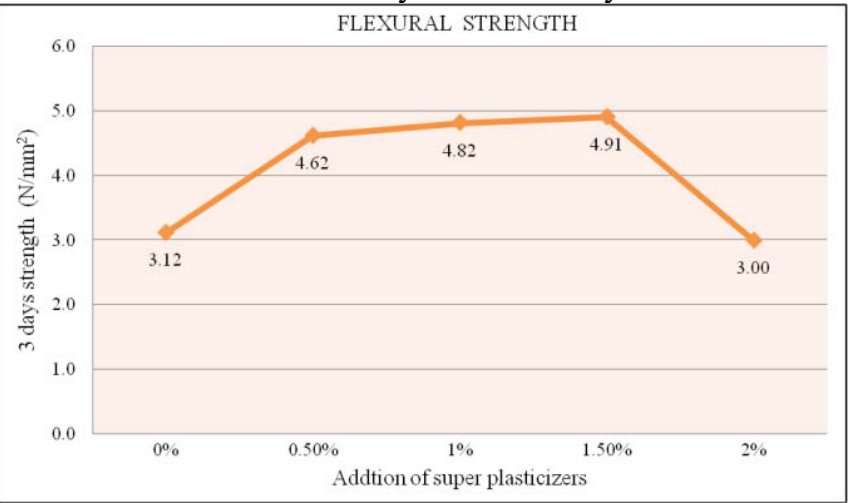

Figure 16: Graphs drawn between Flexural strength vs Addition of Super Plastisizer for 3 days

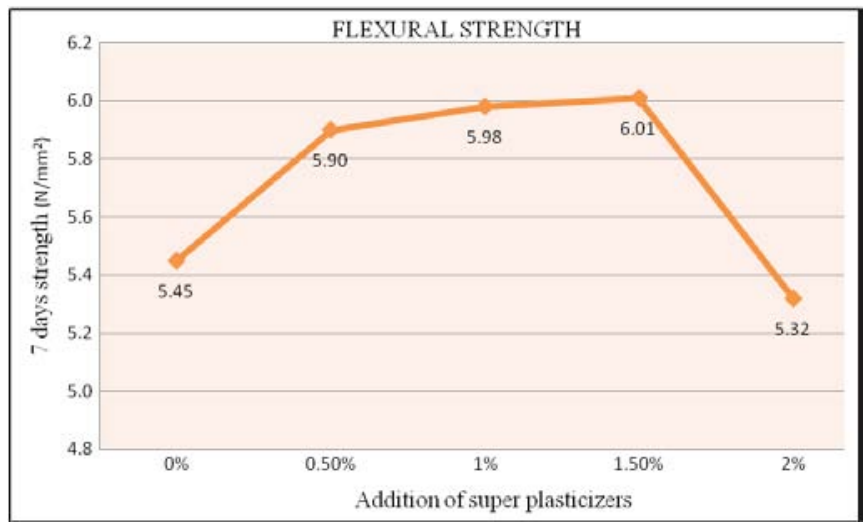

Figure 17: Graphs drawn between Flexural strength vs Addition of Super Plastisizer for 7 days

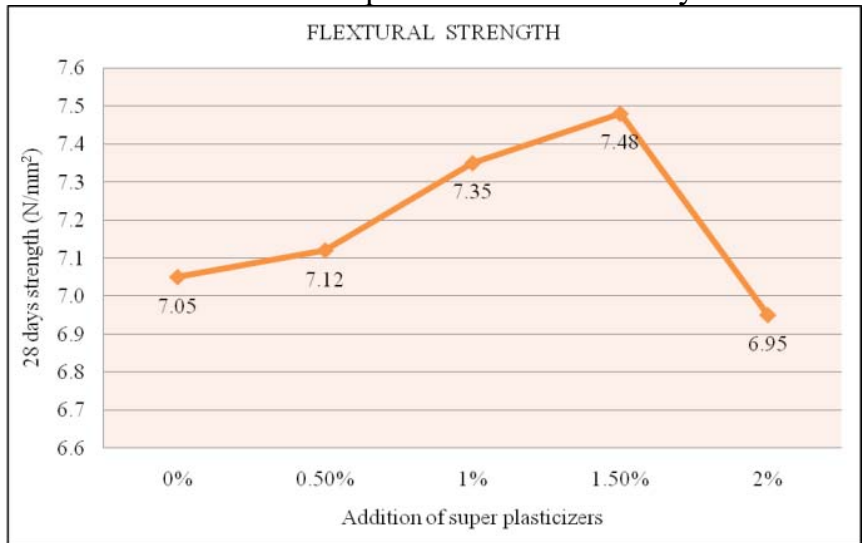

Figure 18: Graphs drawn between Flexural strength vs Addition of Super Plastisizer for 28 days

\section{Conclusions}

1) Fly ash is added at different proportions namely $0 \%$, $10 \%, 20 \%, 30 \%$ and $40 \%$.

2) For 43 grade cement with M40 mix, by adding up to $30 \%$ of fly ash to the cement, the strength is increased and by adding $40 \%$ of fly ash the strength is decreasing.

3) The test results show that on addition of $30 \%$ of fly ash to cement it has gained maximum strength at 28 days period but the rate of strength gain compared to ordinary Portland cement concrete OPCC is at slower rate at initial days.

4) The compressive strength increased by $22.44 \%$, split tensile strength increased by $18.37 \%$ and flexural strength increased by $16.18 \%$ when compare to normal concrete.

5) By use of fly ash as admixture, the cost of construction is also considerably reduced.

6) Non-biodegradable fly ash is effectively utilized in H.P.C, so it reduces the disposal problem of fly ash.

7) For 43 grade cement with M40 mix, by adding $0 \%$, $0.5 \%, 1.0 \%, 1.5 \%$ of super plasticizer to the mix prepared the strength is slightly increased and at adding $2.0 \%$ of plasticizer to the mix prepared the strength will slightly decreased.

8) The test results show that on addition of $1.5 \%$ of super plasticizers to concrete it has gained maximum strength at 28 days period

9) The compressive strength increased by $20.22 \%$, split tensile strength increased by $16.32 \%$ and flexural strength increased by $13.46 \%$ when compare to normal concrete.

10) Super plasticizer may not increase the strength of concrete directly. But it helps in reducing the w/c ratio. Which in turn result in the increase of strength of concrete due to reduction of $\mathrm{w} / \mathrm{c}$ ratio.

11) It is concluded that when compare to super plasticizer, fly ash gives more desirable properties to concrete and eco friendly.

\section{References}

[1] A\&Court, C. L., "Mix Design and Abrasion Resistance of Concrete," Symposium on Mix Design and Quality Control of Concrete, Cement and Concrete Association, London (1954)

[2] Abdun-Nur, E. A., Fly Ash in Concrete, Highway Research Board Bulletin 284, Washington, D.C. (1961)

[3] ASTM Committee C-9, Manual of Concrete Testing, 1976 Annual Book of ASTM Standards, Part 14, Philadelphia (1976)

[4] ASTM, Manual of Cement Testing, 1988 Annual Book of ASTM Standards, Vol. 04.01 (1988)

[5] ASTM Committee C-9, Manual of Aggregate and Concrete Testing, 1989 Annual Book of ASTM Standards, Part 14, Philadelphia (1989)

[6] American Coal Ash Association, Proceeding: Eigth International Ash Utilization Symposium, 
[7] J. M. Hodgkinson (2000). Mechanical Testing of Advanced Fibre Composites. Cambridge: Woodhead Publishing, Ltd. p. 132-133.

[8] William D. Callister, Jr.Materials Science and Engineering.Hoken:John Wiley \& Sons,Inc.,2003pegggy carrasquillo, chapter 14, SYM STP 169C,significancies of testing and properties of concrete and concrete making materials, American society for testing and materials west Conshohocken, PA.

[9] "Significance of Tests and Properties of Concrete and Concrete-Making Materials," Chapter 12 on Strength, ASTM STP 169B.

[10] "Studies of Flexural Strength of Concrete, Part 3, Effects of Variations in Testing Procedures," by Stanton Walker and D.L. Bloem, NRMCA Publication No. 75 (ASTM Proceedings, Volume 57, 1957).

[11] "Variation of Laboratory Concrete Flexural Strength Tests," by W. Charles Greer, Jr., ASTM, Cement, Concrete and Aggregates, Winter, 1983.

[12] "Concrete Mixture Evaluation and Acceptance for Air Field Pavements" by Richard O.Meininger and Norman R. Nelson, ASCE Air Field Pavement Conference, September, 1991. NRMCA Publication No. 178.

[13] ASTM D3967-95a, 1996, Standard test method for splitting tensile strength of rock core specimens

[14] ASTM C496 Splitting Tensile Strength of Cylindrical Concrete Specimens

[15] J.Premalatha and R.Sundara Rajan, strength properties of high strength fibrous concrete, THE INDIAN CONCRETE JOURNAL JULY 2007,PP.(37-41)

[16] Concrete Technology by M.S.SHETTY.

[17] Concrete Technology by M.L.GAMBHIR .

[18] Design of concrete mixes by Dr.N.KRISHNA RAJU.

[19] Super plasticizers in Concrete by V.S.RAMACHANDRAN

[20] Properties of concrete by A.M.NEVILLE.

\section{Author Profile}

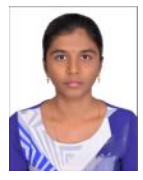

Shanagonda Akhila received B.Tech and M.Tech degree in CIVIL Engineering and Structures under JNTU HYDERABAD in 2012 and 2014 respectively. Working as Assistant Professor in Department of Civil Engineering at Vignan's Institute of Technology and Aeronautical Engineering.

Kolla Aswani Chandh received B.Tech and M.Tech degree in CIVIL Engineering and Transportation Engineering under JNTU KAKINADA in 2012 and 2016 respectively. Working as Assistant Professor in
Department of Civil Engineering at Vignan's Institute of Technology and Aeronautical Engineering. 